\title{
Contes, édition critique établie par Anne Defrance et Jean-François Perrin
}

\section{Paola Sosso}

\section{Q OpenEdition \\ 1 Journals}

\section{Edizione digitale}

URL: http://journals.openedition.org/studifrancesi/7569

DOI: 10.4000/studifrancesi.7569

ISSN: 2421-5856

\section{Editore}

Rosenberg \& Sellier

\section{Edizione cartacea}

Data di pubblicazione: 1 décembre 2009

Paginazione: 623

ISSN: 0039-2944

\section{Notizia bibliografica digitale}

Paola Sosso, «Contes, édition critique établie par Anne Defrance et Jean-François Perrin», Studi

Francesi [Online], 159 (LIII | III) | 2009, online dal 30 novembre 2015, consultato il 09 janvier 2021. URL: http://journals.openedition.org/studifrancesi/7569; DOI: https://doi.org/10.4000/studifrancesi.7569

Questo documento è stato generato automaticamente il 9 janvier 2021.

\section{(c) (i) (9)}

Studi Francesi è distribuita con Licenza Creative Commons Attribuzione - Non commerciale - Non opere derivate 4.0 Internazionale. 


\title{
Contes, édition critique établie par Anne Defrance et Jean-François Perrin
}

\author{
Paola Sosso
}

\section{NOTIZIA}

ANTOINE HAMILTON, JEAN-JACQUES ROUSSEAU, HENRI PAJON, JACQUES CAZOTTE, CARL GUSTAV TESSIN, CHARLES DUCLOS, DENIS DIDEROT, Contes, édition critique établie par Anne DEFRANCE et JeanFrançois PERRIN, Paris, Champion, 2008 («Bibliothèque des Génies et des Fées», 16), pp. 1590.

1 Nel 1730, con la pubblicazione della trilogia di Hamilton (Le Bélier, Histoire de Fleur d'Epine, Les Quatre Facardins, qui presentati insieme a L'Enchanteur Faustus, Zeneyde e La Pyramide et le cheval d'or) il conte merveilleux si apre al regno della satira, della licenza e del persiflage attraverso l'arte della provocazione, i sarcasmi agghiaccianti, gli equivoci e la riscrittura burlesca. Certo sarà Crébillon a inventare, con Tanzaï (1734) la formula che verrà ripresa e tanto imitata del conte merveilleux satirico-licencieux, ma non si deve dimenticare che l'impatto dell'opera di Hamiton fu considerevole e duraturo. La pubblicazione di questi testi, in gran parte dimenticati, mostra la loro inattesa attualità: se il testo di Tessin (Faunillane ou L'Infante Jaune. Conte) appare ancora un gioco gratuito, il tono cambia con le accuse di Rousseau contro l'istituzione monarchica ne La Reine Fantasque, gli attacchi di Diderot nei confronti delle credenze religiose (L'oiseau blanc, conte bleu), la denuncia della superficialità e le caricature di Duclos (Acajou et Zirphile, conte), il rifiuto di qualsiasi dogma da parte di Cazotte (La Patte du chat, conte zinzimois, Les Mille et Une Fadaises. Contes à dormir debout. Ouvrage dans un goût très moderne; La belle par accident, conte de fée; Le Plaisir; Aventure du Pèlerin, conte moral; L'Honneur perdu et recouvré en partie et revanche, ou Rien de fait, Nouvelle Héroïque) e gli anti-eroi di Pajon (Histoire du Prince Soly, surnommé Prenany, et de la Princesse Fêlée). In questa nuova 
raccolta ogni testo è preceduto da un'accurata introduzione, da una approfondita bibliografia, da alcune informazioni sull'opera e sull'edizione critica e seguito da appendici di approfondimento e dossiers relativi alla fortuna dell'opera. Chiudono il volume il riassunto dei racconti e l'indice dei personaggi. 